\title{
Seasonal Incidence of Sucking Pests of Groundnut (Arachis hypogaea L.)
}

\author{
V.K. Nigude, S.A. Patil, A.S. Bagade* and P.B. Mohite \\ Department of Agril. Entomology, College of Agriculture, Kolhapur, Mahatma Phule Krishi \\ Vidyapeeth, Rahuri-413722, India \\ *Corresponding author
}

A B S T R A C T

\begin{tabular}{|l|}
\hline Ke y w or d s \\
Groundnut, \\
$\begin{array}{l}\text { Seasonal incidence, } \\
\text { Thrips, Jassid }\end{array}$ \\
\hline Article Info \\
\hline $\begin{array}{l}\text { Accepted: } \\
\text { 06 December } 2017 \\
\text { Available Online: } \\
\text { 10 January } 2018\end{array}$ \\
\hline
\end{tabular}

Seasonal Incidence of sucking pests of groundnut (Arachis hypogaea L.)" was studied during July to October 2016, at Research farm, College of agriculture, Kolhapur. Groundnut crop was infested by Jassid (Empoascakerri Pruthi), Thrips (Scirtotharips dorsalis Hood). The study revealed that the incidence of jassid started in $2^{\text {nd }}$ week of August; and thrips $1^{\text {st }}$ week of August. The population of Jassid, Empoascakerri (Pruthi) the population steadily increased and reached to its peak in the $35^{\text {th }} \mathrm{MW}$ corresponding to September 1st week 3.06 jassids/3 leaves. The population of thrips, Scirtothrips dorsalis (Hood) The population started increasing slowly and reached to its peak in the $38^{\text {th }} \mathrm{MW}$ corresponding to September $4^{\text {th }}$ week 4.20 thrips/3 leaves. The population of jassid showed negatively non-significant with temperature and rainfall and positively associated with relative humidity. The thrips population was negatively non-significant with temperature and rainfall and positively and significantly associated with relative humidity.

\section{Introduction}

Groundnut (Arachis hypogaea L.) is an annual legume crop, also known as peanut, earthnut, monkey- nut and goobers. It forms the world's largest source of edible oil and ranks $13^{\text {th }}$ among the food crops and is also $4^{\text {th }}$ most important oil seed crop of the world. It is grown in tropical and subtropical countries. Cultivated groundnut has been reported from South America (Weiss, 2000). It is grown in 26.4 million hectares with a production of 38.20 million tones and productivity of $691 \mathrm{~kg}$ $\mathrm{ha}^{-1}$ (FAO, 2010). Asia posses $1^{\text {st }}$ rank in area $(63.4 \%)$ and production (71.1\%). Major groundnut countries are India (26\%), China
(19\%) and Nigeria (11\%). In India is mainly grown in the southern and north-western states; Gujarat, Andhra Pradesh, Tamilnadu, Karnataka, Maharashtra, and Madhya Pradesh together occupying about 90 percent of the groundnut area in the country.

The major insect pest of groundnut are the groundnut Aphid (Aphis craccivora Koch), Leaf miner (Stomopteryx nertara meyrick), Stem borer (Sphenoptera perotett camron), White grub (Holotrichia consainguinia Blanchard), Bihar hairy caterpillar (Spilosoma oblique walker), Tobacco caterpillar (Spodoptera litura Fab.), Red hairy caterpillar (Amsacta albistriga Butler), Jassid (Empoasca 
kerri Pruthi), Thrips (Scritothrips dorsalis), Termite (Odontotermesobesus Rambur) as reported Atwal and Dhaliwal, (2008). However aphid was not considerd to be a serious pest of groundnut until late 1980 (Nandgopal, 1992).

\section{Materials and Methods}

The experiment was conducted during Kharif 2016 at College of agriculture, Kolhapur to investigate the Seasonal Incidence of Sucking Pests of Groundnut (Arachis hypogaea L.) Variety TAG -24 was sown under natural conditions without spraying the insecticides in plot size $3.0 \mathrm{~m} \mathrm{x} 1.80 \mathrm{~m}$ with $30 \mathrm{~cm}$ row to row and $10 \mathrm{~cm}$ plant to plant spacing. The population of sucking pests viz., Jassid (Empoascakerri Pruthi) and Thrips (Scritothrips dorsalis Hood) were recorded at weekly intervals during morning hours between 7.00 am to $9.00 \mathrm{am}$ on five randomly selected and tagged in each plot by using sampling techniques given by Yeotiker et al., (2015) population was counted on three leaves. The data were subjected to statistical analysis and correlation coefficient was worked out.

\section{Results and Discussion}

The mean population of Jassid (Empoasca kerri Pruthi) and Thrips (Scritothrips dorsalis Hood) has been presented in Table 1 during the course of investigation, Jassid, Empoasca kerri Pruthi; Thrips, Scirtothrips dorsalis were recorded sucking insect pests of groundnut.

\section{Jassid, Empoasca kerri (Pruthi)}

The data presented in the Table 1 clearly indicated that the jassids incidence first appeared in the $32^{\text {nd }}$ MW corresponding to the August $2^{\text {nd }}$ week with mean population 0.33 jassids $/ 3$ leavas. The population steadily increased and reached to its peak in the $35^{\text {th }}$ MW corresponding to September $1^{\text {st }}$ week (3.06 jassids/3 leaves) when the maximum temperature was $28.010 \mathrm{C}$, morning relative humidity 90 per cent and $1.10 \mathrm{~mm}$ rainfall.

The population of the jassids declined thereafter from 3.00 at $36^{\text {th }} \mathrm{MW}$ corresponding to September 2nd week to 0.30 jassids $/ 3$ leaves at $42^{\text {nd }} \quad M W$ corresponding to October $3^{\text {rd }}$ week.

Table.1 Seasonal incidence of sucking insect pests in groundnut variety TAG -24 during kharif, 2016

\begin{tabular}{|l|l|c|c|l|c|c|c|}
\hline SMW & Date & Temperature & Humidity & \multicolumn{2}{|c|}{ Rainfall } & \multicolumn{3}{|c|}{ Avg. number of sucking insect pests on 3leaves } \\
\hline No. & & $\left({ }^{\circ} \mathbf{C}\right)$ & $(\%)$ & $(\mathrm{mm})$ & jassid & Thrips \\
\hline $\mathbf{3 1}$ & 30 July-5 Aug & 25.00 & 89.00 & 166.7 & 0.0 & 0.90 \\
$\mathbf{3 2}$ & 6 Aug-12 Aug & 25.80 & 92.00 & 100.4 & 0.33 & 1.20 \\
\hline $\mathbf{3 3}$ & 13 Aug-19 Aug & 26.70 & 88.00 & 16.7 & 2.64 & 3.03 \\
\hline $\mathbf{3 4}$ & 20 Aug-26 Aug & 27.20 & 89.00 & 27.1 & 3.03 & 3.93 \\
\hline $\mathbf{3 5}$ & 27 Aug-2 Sept & 28.10 & 90.00 & 01.1 & 3.06 & 3.17 \\
\hline $\mathbf{3 6}$ & 3 Sept-9 Sept & 28.50 & 83.00 & 01.9 & 3.00 & 3.26 \\
\hline $\mathbf{3 7}$ & 10 Sept-16 Sept & 28.30 & 85.00 & 17.9 & 2.50 & 3.30 \\
\hline $\mathbf{3 8}$ & 17 Sept-23 Sept & 26.00 & 86.00 & 44.0 & 2.80 & 4.20 & \\
\hline $\mathbf{3 9}$ & 24 Sept-30 Sept & 29.10 & 83.00 & 01.5 & 1.50 & 3.50 \\
\hline $\mathbf{4 0}$ & 1 Oct-7 Oct & 28.50 & 82.00 & 02.7 & 0.80 & 1.74 \\
\hline $\mathbf{4 1}$ & 8 Oct-14 Oct & 30.70 & 82.00 & 29.9 & 0.60 & 1.02 \\
\hline $\mathbf{4 2}$ & 15 Oct-21 Oct & 31.90 & 81.00 & 0.0 & 0.30 & 0.90 \\
\hline $\mathbf{4 3}$ & 22 Oct-28 Oct & 31.70 & 76.00 & $\mathbf{0 . 0}$ & $\mathbf{0 . 0 0}$ & $\mathbf{0 . 0 0}$ & \\
\hline
\end{tabular}


Table.2 Correlation coefficient between abiotic factors and population of sucking pests of groundnut

\begin{tabular}{|c|c|c|}
\hline Parameters & Jassid & Thrips \\
\hline Temperature & -0.03872 & -0.08251 \\
\hline Humidity (\%) & $0.562916^{*}$ & $0.545565^{*}$ \\
\hline Rainfall (mm) & -0.382706 & -0.27669 \\
\hline
\end{tabular}

* Significant at 5 per cent level.

The correlation coefficient was compared between the jassids population and weather parameters. The analysis in the Table 2 revealed that jassids population was negatively non-significant with temperature $(-0.03)$, rainfall $(-0.38)$ and positively associated with relative humidity $(0.56)$.

\section{Thrips, Scirtothrips dorsalis (Hood)}

The data presented in the Table 2 clearly indicated that the thrips incidence first appeared in the 31st MW corresponding to the August $1^{\text {st }}$ week with mean population 0.90 thrips $/ 3$ leaves. The population started increasing slowly and reached to its peak in the 38th MW corresponding to September $4^{\text {th }}$ week (4.20 thrips/3 leaves) when the maximum temperature was $260 \mathrm{C}$, morning relative humidity 86 per cent and $44 \mathrm{~mm}$ rainfall. The population of the thrips declined thereafter from 3.50 at $39^{\text {th }} \mathrm{MW}$ corresponding to September 5th week to 0.90 thrips $/ 3$ leaves at $42^{\text {nd }}$ MW corresponding to October $3^{\text {rd }}$ week.

The correlation coefficient was compared between the thrips population and weather parameters. The analysis indicated in the Table 2 revealed that thrips population was negatively non-significant with temperature $(-0.08)$ and rainfall $(-0.27)$ and positively and significantly associated with relative humidity (0.54). These findings are in harmony with the results of Yadav et al., (2012) who reported that the incidence of jassids started in $2^{\text {nd }}$ week of August, increased slowly and attained the peak in the second week of September. Similar results were also reported by Yadav et al., (2012) and Kandakoor et al., (2012) that temperature was non significantly and negatively correlated with jassid incidence in groundnut.

Yadav et al., (2012) reported that thrips population was negatively correlated with temperature and positively associated with relative humidity which confirms the present findings.

\section{References}

Atwal, A.S. and Dhaliwal, G.S. 2008. Agricultural pests of south Asia and their management. Publ. Rajender nagar, Ludhiana, pp.274-277

FAO 2010. FAO Production Year book, Vol. 60.

Kandakoor, Subhash B. Khan, Khader H., Gowda, G. Basana. Chakravarti G.B., A. K. Kumar Ashok, C.T. and Vankataravana, P. 2012. The incidence and abundance of sucking insect pests on groundnut. ISSN 09734031, Current Biotica, 6(3): 342-348.

Nandgopal, V. 1992. Studied on integrated pest management in groundnut in saurastra $\mathrm{Ph}$. D. thesis submitted to Saurasta University, Rajkot, Pesticides, 8:246.

Weiss, E. A. 2000. Oilseed Crops. Publ. by Blackwell Science, London. p. 13. 
Yadav, P. C., Sharma, U. S., Ameta, O. P. and Padiwal, N. K. 2012. Seasonal incidence of major sucking insect pests of Groundnut (Arachis hypogaea L.). Indian Journal of Applied Entomology, 26(1): 57-59.

\section{How to cite this article:}

Nigude, V.K., S.A. Patil, A.S. Bagade and Mohite, P.B. 2018. Seasonal Incidence of Sucking Pests of Groundnut (Arachis hypogaea L.). Int.J.Curr.Microbiol.App.Sci. 7(01): 558-561. doi: https://doi.org/10.20546/ijcmas.2018.701.066
Yeotikar, S. G., More, D. G. and Gaikwad, B. B. 2015. Seasonal incidence of major insect pests of soybean. Indian J. agric. Sci., 39(4): 341-346. 